\title{
GROUNDWATER MANAGEMENT FOR IRRIGATED AGRICULTURE IN SOUTH-EASTERN ALGERIA BY APPROACHING CROP WATER NEEDS
}

\author{
Hassina SAADI * \\ Department of Agronomy, Mohamed Khider University of Biskra, Biskra, \\ e-mail: hassina.saadi@yahoo.com \\ Mahmoud DEBABECHE \\ Larghyde Laboratory, Mohamed Khider University of Biskra, Biskra, Algeria, \\ e-mail: mahmoud.debabeche@univ-biskra.dz \\ Farid TRAORE \\ Institute of the Environment and Agricultural Research, Ouagadougou, Burkina Faso \\ e-mail: farid.traore@yahoo.com
}

Citation: Saadi, H., Debabeche, M., \& Traore, F. (2021). Groundwater Management for Irrigated Agriculture in South-Eastern Algeria by Approaching Crop Water Needs. Analele Universităţii din Oradea, Seria Geografie, $31(1), \quad 80-88$. https://doi.org/10.30892/auog.311109-858

\begin{abstract}
The demand for irrigation is growing and will continue to grow in the future due to increasing food demand and climate change. Data on current and future demands are essential for better management and planning of water resources use. The province of Biskra is ranked as the largest consumer of irrigation water in the cities of South East Algeria with $42 \%$ of annual consumption. Under the arid climatic conditions of this region, it is inevitable to irrigate and the majority of irrigation water comes from groundwater. The objective of our study is to evaluate the irrigation water withdrawals in the region using the agro-meteorological model CROPWAT for the 2014-2015 campaign over the entire province, and to compare them with the official data of the Directorate of Water Resources Services (DRE) and the Sahara River Basin Agency (ABHS). Our results were superior to their data and the water consumption per hectare of water was also superior to the results of the SASS (2015) but similar to the Döll (2010). With increasing withdrawals and a decrease in recharge, we could fear economic and ecological problems in a region under severe water stress.
\end{abstract}

Key words: Biskra, crop need, water abstraction, Algeria

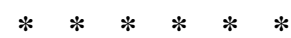

\section{INTRODUCTION}

It is widely known that water is an essential element for the existence of all forms of life. Water is now considered a central element in the sustainable management of natural resources (Kadi, 2014). The agricultural sector alone captures about $70 \%$ of the world's freshwater (up to 90\% in some high-growth economies, UNESCO-WWAP, 2012), as irrigated land provides more 
than $40 \%$ of food production (OECD, 2002; Lejars 2017). In addition, over the last fifty years the area of agricultural land has doubled and this can be interpreted as increasing pressure on water resources (Zingaro, 2017). Indeed, population growth leads to higher and higher demands in terms of quality and quantity of water resources (Funk and Brown, 2009; Belaqziz, 2014).

This growing demand is largely met by groundwater, especially in regions that often face surface water stress (Wada et al., 2010). With a global abstraction rate of 800 to $1,000 \mathrm{~km}^{3} /$ year (Jarvis, 2012; Margat and van der Gun, 2013; Velis, 2017), these extractions mean that groundwater reserves are declining, with about $20 \%$ of the world's aquifers in a state of overexploitation (Gleeson et al., 2012). If, however, groundwater withdrawals cannot be compensated by recharge or reduced flow over a number of years, groundwater depletion will result (Döll, 2014). Increased water abstraction exacerbates already widespread water scarcity conditions in semi-arid and arid regions (World Water Assessment Programme, 2003; Hanasaki et al., 2008; Döll et al., 2009; Kummu et al., 2010; Vörösmarty et al., 2010; Wada, 2014). By 2050, global agricultural production will probably need to double to meet demand, according to Tilman et al., 2011; Alexandratos and Bruinsma 2012; Valin et al., 2014; Falkenmark (2015) and Jägermeyr et al., (2016) call for a high level of international consideration of integrated irrigation water management. Hydrogeologists agree that the current development of groundwater-based agriculture is unsustainable (Leduc et al., 2017).

Already Döll and Siebert (2002) had estimated the average net irrigation needs for North Africa at $66.4 \mathrm{~km}^{3} /$ year. Algeria is one of the largest countries in North Africa, with a surface area of $2,381741 \mathrm{~km}^{2}$. The steppe occupies $8.5 \%$ of the total area, the coastal fringe (mountains and plains) $7.5 \%$ and the Sahara, $84 \%$, i.e. the majority of the country. Water resources abstracted in 2012 are estimated at 8,425 million $\mathrm{m}^{3}$, of which 4,800 million $\mathrm{m}^{3}$ is surface water, 3,000 million $\mathrm{m}^{3}$ is groundwater, well above the annual renewable volume, and 615 million $\mathrm{m}^{3}$ is desalinated water (Eurostat, 2015). According to the statistics of the Ministry in charge of Agriculture (MADR), the irrigated areas of the country would have thus multiplied by 3.7 over the last two decades, from 350,000 ha in 2000 to 928,955 ha in 2008 and to more than 1.3 million hectares in 2017 (Bessaoud, 2019). The water withdrawal rate for the agricultural share seems to correspond to 59\% (Eurostat, 2015). Provinces of Biskra and El Oued in the south-east of the country alone have nearly 17 per cent of the irrigated area in Algeria (Bessaoud, 2019). Annual water consumption levels for domestic needs in the provinces of Biskra and El Oued are respectively $42 \%$ and $18 \%$ (OASS 2015). Biskra is the gateway to the Sahara; its economic development is essentially based on the availability of water for agriculture. Groundwater is a non-renewable resource in the fragile regions of the world's arid ecosystems, and its exploitation requires sustainable management of these resources (Hashim, 2012). Their non-reasoned exploitation by farmers generates a risk of overexploitation, for the aquifers of Northern Algeria, with an average exploitation rate of $80 \%$ (Faysse, 2011).

This intensification generates a certain number of problems, mainly the regular drop in water levels, the increase in pumping costs and the weakening of artesianism (OSS, 2003). Consequently, groundwater management is essential to ensure its sustainable use (Dalin, 2019). It is necessary to estimate the pressure on these water resources for irrigation. It is in this context that our study aims to evaluate the abstraction of irrigation water in the Biskra region and compare the results obtained with the abstraction data of the Water Resources Services Directorate (DRE) and the Sahara River Basin Agency (ABHS). There are many studies to estimate water abstraction for irrigation, such as field surveys that require a budget, energy consumption and estimation of crop water requirements. Our study assumes that in the absence of fairly binding rules on the use of groundwater resources for agriculture, crop water needs are more or less met. Based on this assumption, we apply an efficiency coefficient to our estimate of total annual water requirements that approximates the actual amounts withdrawn in a year. The approach adopted for the estimation of water requirements is based on the calculation of crop evapotranspiration through the use of the CROPWAT model. 


\section{MATERIAL AND METHOD}

\section{Presentation of the study area}

The province (Willaya) of Biskra covers an area of $21,671 \mathrm{~km}^{2}$. The whole province is divided into several agro-climatic zones (plain and steppe). The study area is located between latitudes $33.0^{\circ}$ and $35.5^{\circ}$ north and longitudes $4.0^{\circ}$ and $7.0^{\circ}$ east (figure 1 ). The average altitude is $87 \mathrm{~m}$ above sea level. The region is characterized by its arid climate, hot summers and cold winters. Aridity has been defined as the ratio between the annual sum of precipitation and the annual sum of potential evapotranspiration (Middleton and Thomas, 1997; CGIAR-CSI, 2014; Siebert, 2014). The mean annual temperature is $22^{\circ} \mathrm{C}$. July is the warmest month of the year, while January is the coolest. The average annual precipitation is $148 \mathrm{~mm}$; there is almost no precipitation during the summer months. Potential evapotranspiration is high and can reach 10 to 20 times the amount of water falling (Margat, 1985; Sedrati, 2010).

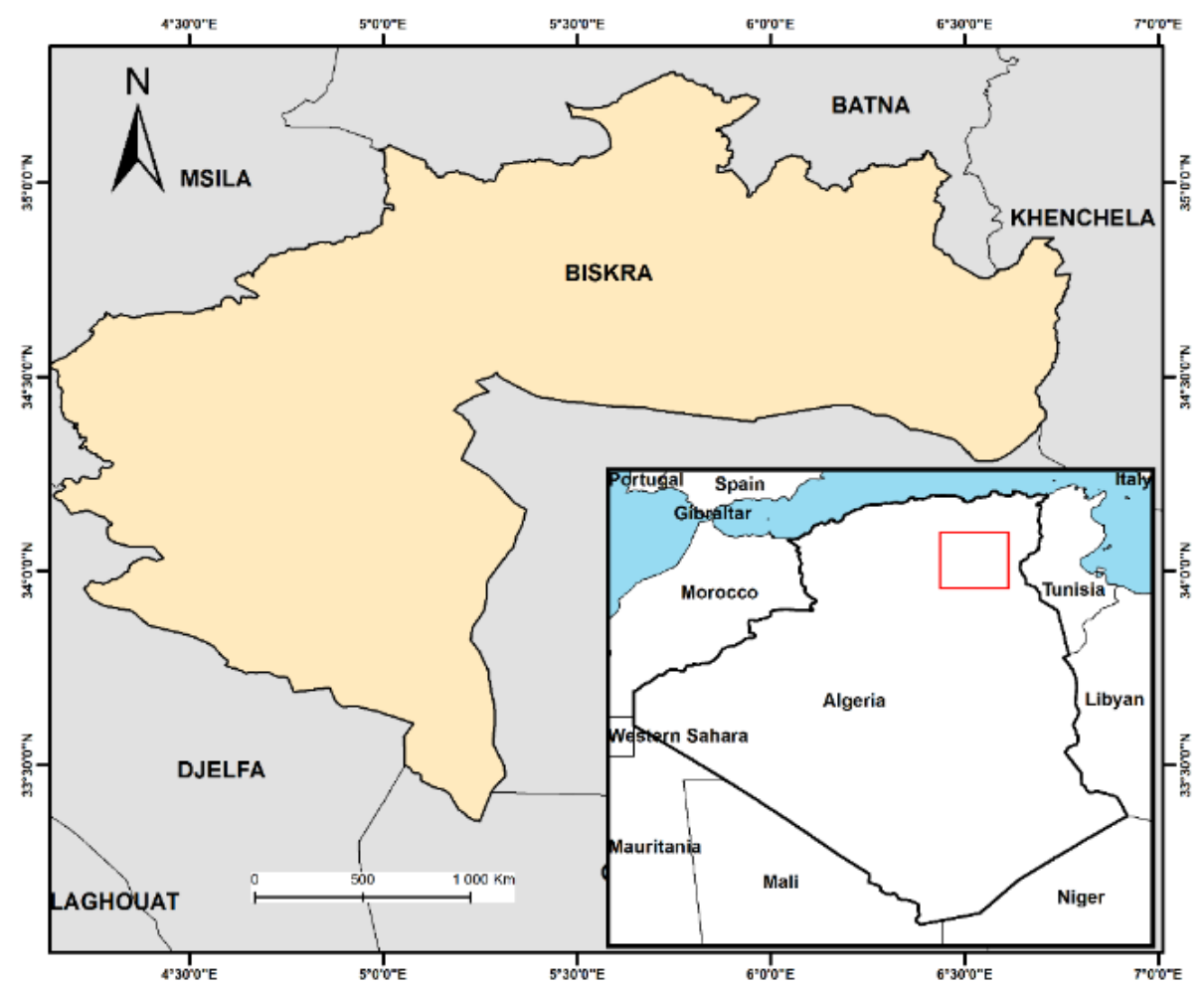

Figure 1. Location of Biskra region

Biskra is one of the Saharan provinces where land reclamation has enabled spectacular agricultural development on a broad pioneer front (Petit et al., 2017). This development is due to irrigation water drawn more than $94 \%$ from groundwater (see Table 1) (MRE, 2009). Farmers also irrigate with surface water. We can enumerate two sources of surface water: run-of-river irrigation using the rivers (often dry, except when it rains) that run through the province, but also water that occasionally runs off from the surrounding mountains (Ould Baba, 2005); and two dams: Foum El Gherza and Fontaines des Gazelles. In Biskra, two main confined aquifers of the Continental Terminal are exploited (Massuel, 2017). These are the Continental terminal (CI) and the Terminal Complex (CT) formations. The term Intercalary Continental refers to the continental episode located between two marine sedimentary cycles: at the base, the Paleozoic cycle which completes 
the Hercynian orogeny, and at the top, the Upper Cretaceous cycle. The Terminal Complex is an inhomogeneous ensemble comprising carbonate formations from the Upper Cretaceous and detrital episodes from the Tertiary, notably from the Miocene (OSS, 2003). The exploited aquifers have shown a general decrease in piezometric heads over the last 40 years, by $90 \mathrm{~m}$ (ANAT, 2003). The region is characterised by a diversification of the crops grown (date palm, cereals and market gardening crops, etc). Biskra is one of the Saharan provinces where land reclamation has enabled spectacular agricultural development on a broad pioneer front (Petit et al., 2017). This development is due to irrigation water drawn more than $94 \%$ from groundwater (see Table 1) (MRE, 2009). Farmers also irrigate with surface water. We can enumerate two sources of surface water: run-of-river irrigation using the rivers (often dry, except when it rains) that run through the province, but also water that occasionally runs off from the surrounding mountains (Ould Baba, 2005); and two dams: Foum El Gherza and Fontaines des Gazelles. In Biskra, two main confined aquifers of the Continental Terminal are exploited (Massuel, 2017). These are the Continental terminal (CI) and the Terminal Complex (CT) formations. The term Intercalary Continental refers to the continental episode located between two marine sedimentary cycles: at the base, the Paleozoic cycle which completes the Hercynian orogeny, and at the top, the Upper Cretaceous cycle. The Terminal Complex is an inhomogeneous ensemble comprising carbonate formations from the Upper Cretaceous and detrital episodes from the Tertiary, notably from the Miocene (OSS, 2003). The exploited aquifers have shown a general decrease in piezometric heads over the last 40 years, by $90 \mathrm{~m}$ (ANAT, 2003). The region is characterised by a diversification of the crops grown (date palm, cereals and market gardening crops, etc).

$$
P d=\frac{|A-B|}{(A+B) \div 2} * 100 \#(1)
$$

\section{D p: Percentage difference \\ A: Calculation Method 1 \\ B: Calculation Method 2}

\section{Calculated water requirements}

In this study, groundwater abstractions for crop irrigation are calculated according to the water needs of plants for the 2014-2015 agricultural seasons. It is assumed here that crop water needs are met and irrigation is carried out with an average efficiency of 70\% (FAO, 1997; Döll, 2010). In our study the simulation of the water needs of the listed crops (41 in total) was carried out using the CROPWAT 8.0 software. This model considers that all crop water demands refer to theoretical evapotranspiration (Aldaya, 2010), which represents the main crops in the province. Some crops could not be considered due to lack of sufficient agronomic data and parameters. These are extrapolated to $100 \%$ of the total cultivated area.

The calculation of irrigation needs by the CROPWAT model uses the approach of Allen et al. 1998 with a single crop coefficient to calculate crop evapotranspiration (etc.). The availability of 26 years of climate data (1989-2015) from the Biskra metrological station was used as a basis for the calculation. The crop parameters (cropping calendars in the area, sowing dates, length of plant growth stages) required for modelling were determined both on the basis of a questionnaire to farmers and communal extension agents and on the basis of the FAO guide by Allen et al. 1998 . Crop coefficients were extracted from the same guide. Statistical data on cultivated areas for the 2014-2015 crop years were provided by the Biskra Agricultural Services Directorate (DSA) and the Ministry of Agriculture and Fisheries. These data concern: date palm (42, 666 ha), cereals (24,120 ha) including wheat (16, $243 \mathrm{ha})$, market gardening (20133.75 ha), fruit trees $(9,681 \mathrm{ha})$, olive trees (4154 ha), alfalfa (10 ha), including alfalfa (10 ha), and industrial crops (1251 ha) 
including tobacco (47 ha). As a simplifying assumption, it was assumed that each type of crop was planted throughout the region at approximately the same time and covered $100 \%$ of the planned area (figure 2).

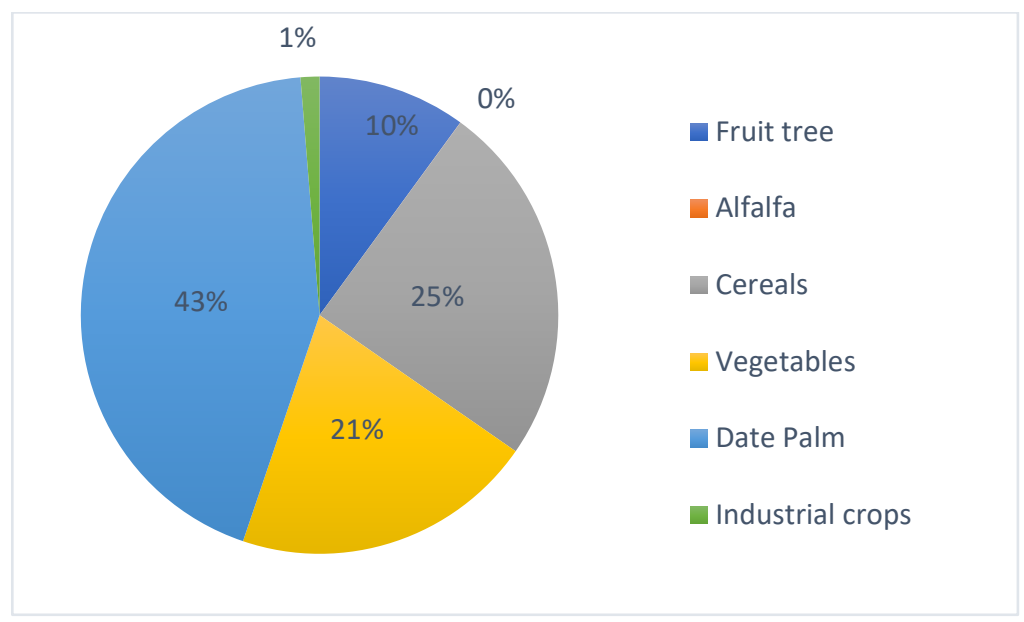

Figure 2. Percentage of area by crop sector

\section{RESULTS AND DISCUSSION}

In Algerian Saharan cities, intense evaporation leads to allocations of up to 10,000 $\mathrm{m}^{3} /$ ha/year (Mutin, 2011; Taabni and El Jihad, 2012). This explains the high potential evapotranspiration in the province of Biskra, over 26 years, estimated at $2.177 \mathrm{~mm} /$ year, according to our calculations the greenhouse reference evapotranspiration is lower than the external reference evapotranspiration, i.e. $993.79 \mathrm{~mm} /$ year. The annual irrigation needs for all crops combined are about $1,027 \mathrm{~mm}^{3} /$ year for the 2014-2015 seasons without taking into account irrigation efficiency (i.e. $70 \%$ efficiency). Setting the efficiency at $70 \%$, the total groundwater consumption for irrigation is estimated at $1.4672 \mathrm{~mm}^{3} /$ year. Figure 3 illustrates the theoretical annual water needs per channel: date palm accounts for more than $69.45 \%$, followed by cereals $13.4 \%$, fruit trees more than $10.02 \%$, market gardening full of fields and under shelter $6.36 \%$, fodder $0.01 \%$. Industrial crops account for only about $0.67 \%$ of total requirements. Whatever the species, agricultural water consumption is seasonally dependent and increases due to evaporative demand until harvest (Allen et al., 1998).

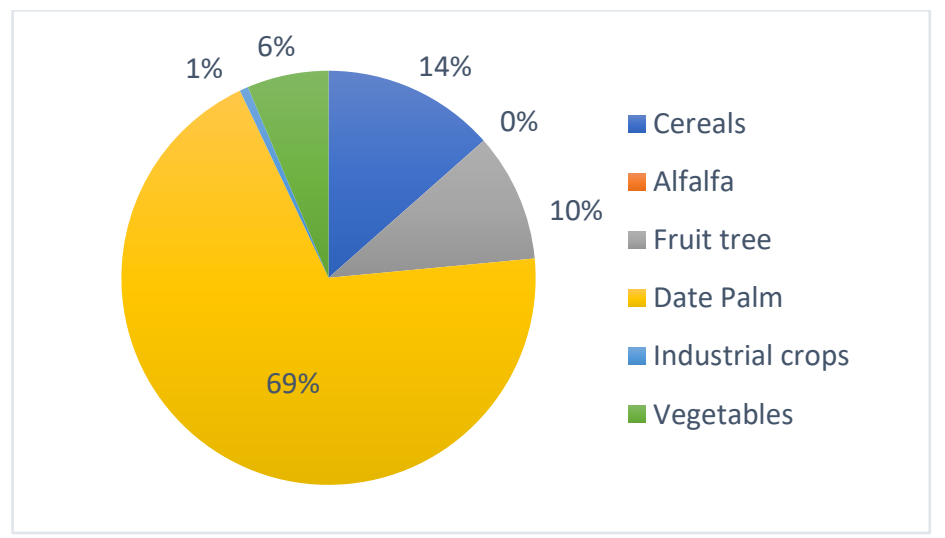

Figure 3. Percentage of Annual Water Requirements by Type of Commodity 
The results of theoretical consumption for agriculture are $1.467 \mathrm{~mm}^{3}$ (Net of irrigation is $1.027 \mathrm{~mm}^{3}$ ). For the 2014-2015 campaign, for the same period, the data on water consumption provided by the ABHS (i.e. $1.141 \mathrm{~mm}^{3}$ ) are higher than those provided by the DRE for the same agricultural campaign 2014-2015, which are of the order of $822 \mathrm{~mm}^{3}$, of which $810 \mathrm{~mm}^{3}$ is for groundwater and $12 \mathrm{~mm}^{3}$ is for surface water. In order to analyze and compare the results with the data provided by the DRE and ABHS sources, we used the percentage difference method (see Table 2).

Table 2. Percentage difference between estimates of groundwater withdrawal, by 3 sources

\begin{tabular}{|c|c|c|c|}
\hline & Saadi et al.* & ABHS & DRE \\
\hline Saadi et al.* & - & 25 & 56,35 \\
\hline ABHS & 25 & - & 32.5 \\
\hline DRE & 56,35 & 32.5 & - \\
\hline
\end{tabular}

The largest discrepancy between estimates of groundwater withdrawals for irrigation is found between the data provided by the DRE and our results. Between our results and the data provided by the ABHS, the difference is relatively smaller. Differences revealed in the comparison of estimates may be due to different calculation methods. The DRE is based on statistical data on the number of authorizations to drill allocated, which are 8219 boreholes. This total does not take into account the pumping points of illicit boreholes, or the contribution of the 3249 wells surveyed by the ABHS during the 2014/2015 campaign, nor run-of-river irrigation, which may explain the underestimation of actual water consumption.

For the ABHS data, the Algerian State is very conscious of the preservation of water resources, which is why it carries out an inventory of water abstraction points every 10 years, as well as the quantities abstracted. These quantities extracted are estimated on the basis of the product of the estimated flow rates in the field and the annual duration of pump operation declared by the farmers. Given the absence of meters, the method is based on the farmer's declarations, which may either underestimate or overestimate the number of hours of pumping.

During 2008, the ANRAH (National Agency for Hydraulic Resources) in a study, estimated the abstractions of irrigation water, in the order of $505.61 \mathrm{~mm}^{3}$ of water, extracted from 6481 boreholes (Sedrati, 2010). During the 2014/2015 campaign, the ABHS carried out another study showing that the withdrawals for irrigation are $1.141 \mathrm{~mm}^{3}$.

It is necessary to highlight the constraints for carrying out these inventories, namely the extent of the region with $21671.2 \mathrm{~km}^{2}$ and 33926 farms (Sogreah, 2009). These constraints make it impossible to inventory all the boreholes. The inventory method requires a great deal of investment and human mobilisation. In addition, farmers can apply more or less irrigation than the crop requires, such as farmers in palm groves (using individual boreholes) who stop irrigation from September to December. This period coincides with the end of the maturity of the dates and the dormant phase of the palms. A survey conducted by the Northern Sahara Aquifer System. (SASS) in 2012 on the cities of South-East Algeria showed that $66 \%$ of the irrigators belong to farms equipped with individual wells (OSS, 2015). Both methods (ABHS and calculated crop water requirements) indicate high water consumption per hectare $11644 \mathrm{~m}^{3} /$ ha/year and 14969 $\mathrm{m}^{3} /$ ha/year (with net irrigation of $10353 \mathrm{~m}^{3} /$ ha/year) respectively for the 2014/2015 season. According to Döll (2010) who used the CROPWAT approach, net irrigation in arid and semi-arid regions is above $1000 \mathrm{~mm} /$ year; in the same study, the Biskra region is between 800-2000 $\mathrm{mm} /$ year. As for ABHS water consumption per hectare of water which is $11644 \mathrm{~m}^{3} / \mathrm{ha} / \mathrm{year}$, it is close to that of SASS (2015) which is: $12383 \mathrm{~m}^{3} / \mathrm{ha} /$ year and which used the pumping method during its surveys in Biskra province in 2012. However, the volume of renewable groundwater resources that can be exploited is $260 \mathrm{Mm} 3 /$ year (MRE, 2009; Lejars, 2017). The estimation of irrigation water use using the CROPWAT model is based on the reported areas The use of remote sensing is recommended, which is of obvious interest for verifying irrigated areas, otherwise the 
water estimate leads to an underestimation or overestimation of the water actually withdrawn by irrigators (Weatherhead and Knox, 2000; Maton, 2006). Two of the methods for estimating water consumption presented can be coupled so that they are complementary: the method by estimation of water needs, which we propose, and the method by estimation of pumped volumes (method known as "by pumping"). The pumping method measures the impact of irrigation water withdrawals and gives information on the entire region without specifically designating the plots where there is poor water management. Moreover, over-exploitation of the water table is only noticed after comparing the refills and withdrawals of water from the water table. Moreover, this method, based on an inventory, is carried out at a frequency of ten years. Conversely, the evapotranspiration method can deal with water management at each site, since water requirements can be calculated for each farm depending on the crops grown. With good extension, the farmer can learn how to manage the irrigation of his farm, which can lead to a rationalization of water use and reduce annual water consumption, thus generating on a regional scale, an economic impact (reducing the cost of pumping), and an ecological impact (saving soil and water). The complementary role of the "pumping" method would be to provide information on the evaluation of water management by agriculture. Finally, it should be highlighted that water optimisation, the irrigation system chosen by the farmer, as well as the efficiency of this system, have a great influence on the levels of water abstraction for agriculture. The use of a drip irrigation system can reduce water losses by up to $50 \%$ (Hochmuth and Hanlon, 2010).

\section{CONCLUSION}

The exploitation of groundwater in the province of Biskra over the last decades has led to considerable economic development. It is essential to assess water resources with regard to their use in order to avoid overexploitation and to ensure their sustainability. Data provided by two national institutes allowed us to have a first approximation on water withdrawals for irrigation. It appears that there are significant differences between our results and those of these two institutes, as each method used has its own biases. However, it must be admitted that the management of groundwater exploitation (Continental Intercalary and Terminal Complex), presents a major challenge between a structural configuration and the climate of the region, which means that the reserves of these two aquifers renew themselves very little. Management must be integrated in terms of quantity and quality. Decision-makers and irrigators must guarantee sustainable water use. Today, most water resources experts agree that water conflicts are not caused by physical water scarcity, but are mainly due to poor water management, since rational groundwater management cannot be based exclusively on a set of laws.

\section{REFERENCES}

Aldaya, M. M., Martínez-Santos, P., \& Llamas, M. R. (2010). Incorporating the water footprint and virtual water into policy: Reflections from the Mancha Occidental Region, Spain. Water Resources Management, 24(5), 941-958.

Alexandratos, N., \& Bruinsma, J. (2012). World agriculture towards 2030/2050: the 2012 revision.

Allen, R.G., Pereira, L.S., Raes, D., \& Smith, M. (1998). Crop evapotranspiration-Guidelines for computing crop water requirements-FAO Irrigation and drainage paper 56. Fao, Rome, 300(9), D05109.

ANAT (Agence Nationale d'Aménagement du Territoire) (2003) Etude schéma directeur des ressources en eau Wilaya de Biskra [Study of the water resources master plan in Biskra], synthesis report, phase II, 60p.

Belaqziz, S. (2014). Une approche d'aide à la décision pour la gestion d'un système d'irrigation gravitaire: modélisation multi-agents, télédétection et optimisation par algorithme évolutionnaire (Doctoral dissertation, Thèse de doctorat. Faculté des Sciences et Techniques de Marrakech, Maroc).

Bessaoud, O., Pellissier, J. P., Rolland, J. P., \& Khechimi, W. (2019). Rapport de synthèse sur l'agriculture en Algérie (Doctoral dissertation, CIHEAM-IAMM). 
CGIAR-CSI: Global Aridity and PET Database. International Food Policy Research Institute (IFPRI). http://www.cgiar-csi.org/data/ global-aridity-and-pet-database. last access: 30 May 2014.

Dalin, C., Taniguchi, M., \& Green, T. R. (2019). Unsustainable groundwater use for global food production and related international trade. Global Sustainability, 2.

Döll, P., \& Siebert, S. (2002). Global modeling of irrigation water requirements. Water resources research, 38(4), 8-1.

Döll, P., Mueller Schmied, H., Schuh, C., Portmann, F. T., \& Eicker, A. (2014). Global-scale assessment of groundwater depletion and related groundwater abstractions: Combining hydrological modeling with information from well observations and GRACE satellites. Water Resources Research, 50(7), 5698-5720.

Eurostat. 2015. Euro-Mediterranean statistics. Base de données Eurostat.

Falkenmark, M., Fox, P., Persson, G., \& Rockström, J. (2001). Water harvesting for upgrading of rainfed agriculture. Problem analysis and research needs, Stockholm International Water Institute.

FAO. (1997). Nations Irrigation potential in Africa: A basin approach. Food and Agriculture Organization.

Faysse, N., Hartani, T., Frija, A., Tazekrit, I., Zairi, C., \& Challouf, A. (2011). Usage agricole des eaux souterraines et initiatives de gestion au Maghreb: défis et opportunités pour un usage durable des aquifères. Note Economique de la BAD, 1-24.

Funk, C. C., \& Brown, M. E. (2009). Declining global per capita agricultural production and warming oceans threaten food security. Food Security, 1(3), 271-289.

Gleeson, T., Wada, Y., Bierkens, M. F., \& Van Beek, L. P. (2012). Water balance of global aquifers revealed by groundwater footprint. Nature, 488(7410), 197-200.

Hanasaki, N., Kanae, S., Oki, T., Masuda, K., Motoya, K., Shirakawa, N., ... \& Tanaka, K. (2008). An integrated model for the assessment of global water resources-Part 2: Applications and assessments. Hydrology and Earth System Sciences, 12(4), 1027-1037.

Hashim, M. A. A., Siam, N., Al-Dosari, A., Asl-Gaadi, K. A., Patil, V. C., Tola, E. H. M., ... \& Samdani, M. S. (2012). Determination of water requirement and crop water productivity of crops grown in the Makkah region of Saudi Arabia. Australian Journal of Basic and Applied Sciences, 6(9), 196-206.

Hochmuth, G., \& Hanlon, E. (2010). Principles of sound fertilizer recommendations. EDIS, 2010(2).

Jägermeyr, J., Gerten, D., Schaphoff, S., Heinke, J., Lucht, W., \& Rockström, J. (2016). Integrated crop water management might sustainably halve the global food gap. Environmental Research Letters, 11(2), 025002.

Jarvis, W. T. (2012). Integrating groundwater boundary matters into catchment management. In The dilemma of boundaries (pp. 161-176). Springer, Tokyo.

Kadi, A.K. (2014). Integrated water resources management (IWRM): The international experience. Integrated water resources management in the 21st century: Revisiting the paradigm, 1.

Kummu, M., Ward, P. J., de Moel, H., \& Varis, O. (2010). Is physical water scarcity a new phenomenon? Global assessment of water shortage over the last two millennia. Environmental Research Letters, 5(3), 034006.

Leduc, C., Pulido-Bosch, A., \& Remini, B. (2017). Anthropization of groundwater resources in the Mediterranean region: processes and challenges. Hydrogeology Journal, 25(6), 1529-1547.

Lejars, C., Daoudi, A., \& Amichi, H. (2017). The key role of supply chain actors in groundwater irrigation development in North Africa. Hydrogeology Journal, 25(6), 1593-1606.

Margat, J. E. A. N. (1985). Hydrologie et ressources en eau des zones arides. Bulletin de la Société géologique de France, 1(7), 1009-1020.

Margat, J., \& Van der Gun, J. (2013). Groundwater around the world: a geographic synopsis. Crc Press.

Massuel, S., Amichi, F., Ameur, F., Calvez, R., Jenhaoui, Z., Bouarfa, S., ... \& Hammani, A. (2017). Considering groundwater use to improve the assessment of groundwater pumping for irrigation in North Africa. Hydrogeology Journal, 25(6), 1565-1577.

Maton, L. (2006). Représentation et simulation des pratiques culturales des agriculteurs à l'échelle régionale pour estimer la demande en eau d'irrigation: application à un basin versant maïsicole du sud-ouest de la France... (Doctoral dissertation).

Middleton, N., \& Thomas, D. (1997). World atlas of desertification.. ed. 2. Arnold, Hodder Headline, PLC.

MRE (Ministère des Ressources en Eau) (2009) Etude d'inventaire et de développement de la PMH. Rapport d'étude du Ministère [Inventory Hydrogeol J (2017) 25:1593-1606 1605 and development study for small and medium hydraulics, Ministry of State in Charge of Water Resources]. MRE, Algiers, Algeria.

OECD countries. Organisation for Economic Co-operation and Development, Environment Directorate, Paris.

OSS (2003). Système Aquifère du Sahara Septentrional. Volume 2 : Hydrogéologie. Projet SASS. Rapport interne. Coupes. Planches. Annexes. Tunis, Tunisie. 275p 
OSS (2003). Système Aquifère du Sahara Septentrional. Volume 2 : Hydrogéologie. Projet SASS. Rapport interne. Coupes. Planches. Annexes. Tunis, Tunisie. 275p.

OSS (2015). Système Aquifère du Sahara Septentrional Pour une meilleure valorisation de l'eau d'irrigation dans le bassin du SASS, Diagnostic et recommandations.35p

OSS (2015). Système Aquifère du Sahara Septentrional Pour une meilleure valorisation de l'eau d'irrigation dans le bassin du SASS, Diagnostic et recommandations.35p.

Ould Baba Sy M. (2005). Recharge et paleorecharge du système aquifère du Sahara septentrional. (Doctoral dissertation, Thése Doctorat, Univ. Tunis el Manar, Tunis, Tunisie, 271 p.).

Petit, O., Kuper, M., López-Gunn, E., Rinaudo, J. D., Daoudi, A., \& Lejars, C. (2017). Can agricultural groundwater economies collapse? An inquiry into the pathways of four groundwater economies under threat. Hydrogeology Journal, 25(6), 1549-1564.

Sedrati, N. (2011). Origines et caracteristiques physico-chimiques des eaux de la wilaya de biskra-sud est algerien (Doctoral dissertation, Annaba).

Siebert, S., Kummu, M., Porkka, M., Döll, P., Ramankutty, N., \& Scanlon, B. R. (2014). A global dataset of the extent of irrigated land from 1900 to 2005. Hydrol. Earth Syst. Sci, 11, 13207-13258.

Sogreah (2009). Étude d'inventaire et de développement de la PMH wilaya de Biskra, 87 pages.

Sogreah, (2009). Étude d'inventaire et de développement de la PMH wilaya de Biskra, 87 pages.

Taabni, M., \& Jihad, M. D. E. (2012). Eau et changement climatique au Maghreb: quelles stratégies d'adaptation?. Les Cahiers d'Outre-Mer. Revue de géographie de Bordeaux, 65(260), 493-518.

Tilman, D., Balzer, C., Hill, J., \& Befort, B. L. (2011). Global food demand and the sustainable intensification of agriculture. Proceedings of the national academy of sciences, 108(50), 20260-20264.

Valin, H., Sands, R. D., Van der Mensbrugghe, D., Nelson, G. C., Ahammad, H., Blanc, E., ... \& Willenbockel, D. (2014). The future of food demand: understanding differences in global economic models. Agricultural Economics, 45(1), 51-67.

Velis, M., Conti, K. I., \& Biermann, F. (2017). Groundwater and human development: synergies and trade-offs within the context of the sustainable development goals. Sustainability science, 12(6), 1007-1017.

Vörösmarty, C. J., McIntyre, P. B., Gessner, M. O., Dudgeon, D., Prusevich, A., Green, P., \& Davies, P. M. (2010). Global threats to human water security and river biodiversity. nature, 467(7315), 555-561.

Wada, Y., Van Beek, L. P., Van Kempen, C. M., Reckman, J. W., Vasak, S., \& Bierkens, M. F. (2010). Global depletion of groundwater resources. Geophysical research letters, 37(20).

Wada, Y., Wisser, D., \& Bierkens, M. F. (2014). Global modeling of withdrawal, allocation and consumptive use of surface water and groundwater resources. Earth System Dynamics, 5(1), 15-40.

Weatherhead, E. K., \& Knox, J. W. (2000). Predicting and mapping the future demand for irrigation water in England and Wales. Agricultural Water Management, 43(2), 203-218.

World Water Assessment Programme (United Nations). (2003). Water for People, Water for Life: The United Nations World Water Development Report: Executive Summary. Unesco Pub.

Zingaro, D., Portoghese, I., \& Giannoccaro, G. (2017). Modelling crop pattern changes and water resources exploitation: A case study. Water, 9(9), 685.

http://www.fao.org/nr/water/aquastat/countries_regions/Profile_segments/DZA-WU_fra.stm

http://www.mae.gov.dz/rapport-algerie_MAEP.pdf

http://www.unesco.org/new/fileadmin/MULTIMEDIA/HQ/SC/pdf/Facts\%20and\%20Figures-FR-low\%20res_02.pdf

Submitted:

January 12,2021
Revised:

May 07, 2021
Accepted and published online

June 30, 2021 